\title{
Low Endemicity and Low Pathogenicity of Rotaviruses Among Rural Children in Costa Rica
}

\author{
A. Simhon, L. Mata, M. Vives, L. Rivera, S. Vargas, \\ G. Ramírez, L. Lizano, G. Catarinella, \\ and J. Azofeifa
}

From the Instituto de Investigaciones en Salud, Universidad de Costa Rica, San José, Costa Rica

\begin{abstract}
Rotaviruses were prospectively studied in 51 rural Costa Rican children from birth to two years. Samples of feces were collected weekly over a 33-month period. Rotavirus was detected in $45(1.04 \%)$ of 4,317 fecal specimens; 39 infections were documented (an incidence of 0.5 infection per child-year), only five of which were associated with diarrhea (a pathogenicity of $12.8 \%$ ). Secretory antibody in fecal extracts, detected in six of 39 infections, was short lived and did not protect against reinfection. Serum antibody was present in $69.6 \%$ of two-year-old children, but was not detected in $18.8 \%$ with documented infections. On the other hand, serum antibody was present in six of 14 children in whom rotavirus was not detected, thus increasing the overall incidence to 0.6 infection per child-year. The combination of prolonged breast-feeding, exposure to a lower infecting dose (compared with urban children), and a higher standard of hygiene than expected may explain the low incidence and low pathogenicity of rotavirus among these rural children.
\end{abstract}

The epidemiology of rotavirus infection in populations observed in their own environment needs further elucidation, particularly in less-developed countries where diarrheal disease takes its highest toll. In Costa Rica, rotavirus was demonstrated as the most important etiologic agent of acute diarrhea among outpatients at the National Children's Hospital in San José [1]. Hospital-based studies are of limited epidemiological value, however, because they are cross-sectional in nature; cover, by definition, the most serious cases that require hospital treatment; and thus, do not reflect the situation in the general population. Consequently, a cohort study was designed in order to study patterns of infection and immunity to rotavirus under natural conditions. This longitudinal study permitted investigation of the

Received for publication 19 February 1985 , and in revised form 8 July 1985.

This work was partly supported by the World Health Organization, The British Overseas Development Administration, the International Development Research Centre of Canada, the U. S. Agency for International Development, the Costa Rican Council for Research and Technology, and the University of Costa Rica. A. S. was supported by the British Council while preparing a Ph.D. thesis at the University of London that contained some of the data presented here

We thank Dr. R. G. Wyatt for providing rotavirus antisera and Professor J. E. Banatvala, Dr. I. L. Chrystie, and B. M. Totterdell for their advice and cooperation.

Please address requests for reprints to Dr. L. Mata, Instituto de Investigaciones en Salud, Universidad de Costa Rica, San José, Costa Rica, Central America. prevalence and incidence of rotavirus infection, serum and coproantibody responses, intrafamilial transmissibility, and the electrophoretic diversity of the genomic RNA of rotavirus strains.

\section{Subjects and Methods}

Longitudinal study. Since 1979, cohorts of children living in the municipality of Puriscal, Costa Rica, have yearly been the subjects of comprehensive studies of child health and growth [2]. The Instituto de Investigaciones en Salud Field Station at Puriscal is located in the district-center town of Santiago; is staffed by a physician, a nurse, a microbiologist, a nutritionist, and three field workers; and was the base of operations from which home visits were made. Puriscal is located in a southern section of the Intermountainous Central Valley (mean elevation, $1,000 \mathrm{~m}$ ). The municipality has an area of 560 $\mathrm{km}^{2}$ divided into eight districts; children in this study lived in three of the districts (Barbacoas, Grifo Alto, and Candelarita). The population density was 47 persons per $\mathrm{km}^{2}$ in 1979 . The terrain is rugged. A fourwheel drive vehicle and considerable walking were required to visit the homes of children in the cohort.

The Costa Rican Social Security System encourages infant deliveries at large maternity hospitals, and over $97 \%$ of babies from Puriscal are born in the Hospital San Juan de Dios in San José. Sixty children from Puriscal were recruited at this hospital from 27 November 1981 to 18 September 1982. 
However, nine were withdrawn from the study by their mothers within a few weeks of its commencement. Thus, a "rural cohort" of 51 children was formed, but three children only remained in the cohort until they were 23,41 , and 66 weeks of age. The remaining 48 children were observed for two complete years.

Diarrhea morbidity and collection of feces. Weekly observation of the children in the rural cohort and weekly testing of fecal specimens for the presence of rotavirus antigen were achieved. Samples of feces were collected by the mothers and retrieved by a field worker who also inquired about the presence of diarrhea and of other symptoms. Diarrhea was defined as the passage of abnormal liquid or semiliquid stools in excess of three per day. Interruption of diarrhea by at least one healthy day separated two diarrheal episodes.

Identification of rotavirus. Undiluted fecal specimens were kept at $4 \mathrm{C}$ and transported to the main laboratories in San José every Friday. Every Monday, samples of feces were made into $10 \%-20 \%$ suspensions in brain-heart infusion broth, and clarified extracts (centrifugation at $500 \mathrm{~g}$ for $30 \mathrm{~min}$ ) were tested by an ELISA (National Institute of Health "pre-post") technique [3] described in detail elsewhere [4]. The households of rotavirus-positive children were then visited, and arrangements were made to collect fecal specimens from all household members and domestic animals until all were negative.

During the observation period, $4,317 \mathrm{fecal}$ specimens were collected and tested. However, 334 (7.6\%) were collected within seven days of a preceding spec- imen and were therefore excluded. Thus, a total of 3,983 specimens representing an equal number of observed child-weeks were included. This represented $77.1 \%$ of the expected child-weeks at risk. The denominator of the population is equivalent to 919.8 child-months or 76.6 child-years.

A rotavirus-positive specimen defined a rotaviruspositive week. A causal association was assumed if rotavirus was detected one week before, during, or one week after an episode of diarrhea. Two rotavirus events were considered independent if separated by three or more rotavirus-negative weeks. The incidence of rotavirus was calculated by using independent episodes only. Prevalence or excretion rates included all rotavirus-positive weeks. Other definitions and calculations were as previously described [4].

Viral RNA studies. Extracts of rotavirus RNA for PAGE were prepared by treating fecal extracts with $1 \%$ SDS followed by extraction with bidistilled phenol, chloroform-isoamyl alcohol, and precipitation with absolute ethanol [5]. A 10\% resolving gel and a 3\% stacking gel (1.5 mm thick) were used to electrophorese RNA extracts [6]. Staining of bands was done by silver precipitation [7].

Antibody to rotavirus. Coproantibody was assayed in all of the first 2,516 ultracentrifuged fecal supernatants by a modified ELISA [8]. Briefly, CV-1grown, single-capsid simian SA-11 antigen (or control antigen in alternate rows) was captured by goat930 antiserum (National Institutes of Health, Bethesda, Md) and supernatants added at a 1:2 dilution. The appropriate alkaline phosphatase-conjugated antibody to IgA, IgM, or IgG was then

Table 1. Study populations.

\begin{tabular}{|c|c|c|c|}
\hline Population & $\begin{array}{l}\text { Hospital } \\
\text { of recruitment }\end{array}$ & $\begin{array}{l}\text { Purpose } \\
\text { of study }\end{array}$ & $\begin{array}{c}\text { Length of } \\
\text { observation, year }\end{array}$ \\
\hline Rural cohort $(n=51)^{*}$ & San Juan de Dios ${ }^{\dagger}$ & $\begin{array}{l}\text { Patterns of infection and } \\
\text { immunity }\end{array}$ & First two years of life, 1981-1984 \\
\hline $\begin{array}{l}\text { Newborn comparison series } \\
\text { no. } 1(n=50)\end{array}$ & San Juan de Dios ${ }^{\dagger}$ & $\begin{array}{l}\text { Nosocomial infection of } \\
\text { newborns }\end{array}$ & First week of life, 1982-1983 \\
\hline $\begin{array}{l}\text { Newborn comparison series } \\
\text { no. } 2 .(n=50)\end{array}$ & Calderón Guardia $\ddagger$ & $\begin{array}{l}\text { Nosocomial infection of } \\
\text { newborns }\end{array}$ & First week of life, 1982-1983 \\
\hline $\begin{array}{l}\text { Urban children with } \\
\text { diarrhea }(n=100)\end{array}$ & National Children's $\S$ & $\begin{array}{l}\text { Transmissibility in } \\
\text { contacts }\end{array}$ & $\begin{array}{c}\text { One week after rotavirus } \\
\text { detection, 1982-1983 }\end{array}$ \\
\hline
\end{tabular}


reacted and substrate finally added. Strong reactions were read with the naked eye and weak ones with a through-the-plate colorimeter (MicroELISA MiniReader 405; Dynatech, Alexandria, Va). Specimens yielding a net absorbance $\geqslant 0.2$ were considered positive. Coproantibody did not persist (see Results). After 31 July 1983 antibody was assayed in supernatants produced within four weeks of detection of rotavirus antigen rather than in all fecal supernatants. For comparison, coproantibody-positive specimens were standardized according to their total immunoglobulin content [9].

Serum antibody to rotavirus was assayed in sera collected from 46 two-year-old children. Five sera were not collected, three of which belonged to children withdrawn from the study. Specific IgG was assayed at a 1:100 serum dilution. Antibody-negative sera and sera with nonspecific reactions were retested at a 1:5 dilution in a blocking assay against SA-11 antigen. These sera were considered positive for antibody if they reduced (i.e., blocked) the absorbance value by at least $50 \%$.

Comparison series of children. The possibility of occurence of nosocomial infection was investigated in children in the rural cohort and, one year later, in two comparison series of 50 newborn infants studied shortly after birth in the Hospital San Juan de Dios and in the Hospital Calderón Guardia, another large maternity hospital also in San José (table 1). In the latter hospital, separation of mothers and infants and formula feeding prevailed at the time of the study, in contrast to part-time rooming-in and colostrum feeding at the Hospital San Juan de Dios, where the infants from Puriscal were born [2].

Furthermore, 100 children from the metropolitan area who were treated for acute diarrhea at the $\mathrm{Na}$ tional Children's Hospital (San José) were studied comparatively for 1982-1983 (table 1). The household contacts of these urban children were studied within a week of rotavirus detection and crossinfection rates in 26 rotavirus-positive urban households were compared with those of the rotaviruspositive rural households. Electrophoretic patterns of viral RNA derived from rural and urban children were also compared.

\section{Results}

Longitudinal study. 1. The neonatal period. Rotaviruses were not detected in the neonatal period in specimens obtained from mothers or infants in the rural cohort while at the Hospital San Juan de Dios or five to seven days postpartum, despite recruitment during the cooler months when detection of rotavirus was most frequent. Partial rooming-in and breast-feeding were customary in this hospital.

2. The postneonatal period. Thirty-two $(62.8 \%)$ of 51 children in the rural cohort excreted rotavirus during the study period; seven (13.7\%) experienced reinfection. (Nineteen [37.2\%] children experienced no infections, as determined by virus shedding.) The interval between primary infection and reinfection ranged from four to 74 weeks (table 2). In $919.8 \mathrm{ob}-$ served child-months, there were 39 independent rotavirus infections (symptomatic and asymptomatic), an overal incidence of 4.2 infections per 100 child-months (or 0.5 episode per child-year; table 3 ). Incidence by age did not show marked variations during the first year of life (3.0-4.9 infections per 100 child-months), but rates fluctuated more in the second year (2.4-6.7 infections per 100 childmonths).

Fifty-one episodes of diarrhea occurred during the

Table 2. Repeated infection with rotavirus in children from Puriscal, 1981-1984.

\begin{tabular}{|c|c|c|c|c|c|}
\hline \multirow[b]{2}{*}{ Child no. } & \multicolumn{2}{|c|}{ Age at infection, weeks } & \multirow[b]{2}{*}{$\begin{array}{l}\text { Interval between } \\
\text { infections, weeks }\end{array}$} & \multicolumn{2}{|c|}{ Clinical source } \\
\hline & $\begin{array}{c}\text { First } \\
\text { infection }\end{array}$ & Reinfection & & $\begin{array}{c}\text { First } \\
\text { infection }\end{array}$ & Reinfection \\
\hline 1610 & 12 & 83 & 71 & - & - \\
\hline 1642 & 64 & 80 & 16 & - & - \\
\hline 1668 & 7 & 59 & 52 & - & - \\
\hline 1707 & 51 & 99 & 48 & Diarrhea & - \\
\hline 1812 & 24 & 28 & 4 & - & - \\
\hline 1949 & 44 & 65 & 21 & - & - \\
\hline 2004 & 9 & 83 & 74 & - & - \\
\hline
\end{tabular}

NOTE. - = asymptomatic infection. 
Table 3. Incidence of diarrhea and of rotavirus diarrhea in 51 children from Puriscal, 1981-1984.

\begin{tabular}{cccccc}
\hline Age, months & $\begin{array}{c}\text { Observed } \\
\text { child-months }\end{array}$ & $\begin{array}{c}\text { Total no. of } \\
\text { diarrheal episodes* }\end{array}$ & $\begin{array}{c}\text { Total no. of } \\
\text { rotavirus infections* }\end{array}$ & $\begin{array}{c}\text { Rotavirus-associated } \\
\text { diarrheal episodes }\end{array}$ & $\begin{array}{c}\text { Rotavirus } \\
\text { pathogenicity }(\%)\end{array}$ \\
\hline $0-2$ & 97.2 & $3(3.1)$ & $4(4.1)$ & 0 & 0 \\
$3-5$ & 100.9 & $8(7.9)$ & $3(3.0)$ & 0 & 0 \\
$6-8$ & 111.8 & $9(8.0)$ & $4(3.6)$ & 0 & 0 \\
$9-11$ & 123.1 & $6(4.9)$ & $6(4.9)$ & $1(0.8)$ & 16.7 \\
$12-14$ & 129.3 & $11(8.5)$ & $8(6.2)$ & $4(3.1)$ & 50.0 \\
$15-17$ & 123.3 & $3(2.4)$ & $3(2.4)$ & 0 & 0 \\
$18-20$ & 119.6 & $7(5.8)$ & $8(6.7)$ & 0 & 0 \\
$21-23$ & 114.6 & $4(3.5)$ & $3(2.6)$ & 0 & 0 \\
Total & 919.8 & $51(5.5)$ & $39(4.2)$ & $5(0.5)$ & 12.8 \\
\hline
\end{tabular}

* No. of episodes or infections (rate per 100 child-months).

$\dagger$ No. of rotavirus diarrheas divided by no. of rotavirus infections (symptomatic and asymptomatic) $\times 100$.

study period, an overall incidence of 5.5 episodes per 100 child-months (or 0.7 episode per child-year; table 3). Diarrhea rates fluctuated from 2.4 to 8.5 per 100 child-months, with the sharpest variations occurring in the first year of life. Although the incidence rate of rotavirus infection was 4.2 to per 100 child-months, that of rotavirus-associated diarrhea was almost eightfold less -0.5 episode per 100 childmonths (or 0.06 episode per child-year). Thus rotavirus pathogenicity was exceedingly low; only five $(12.8 \%)$ of 39 infections resulted in diarrhea (table 3). Five episodes of rotavirus-associated diarrhea occurred in the nine-to-14 month age-group, but the children did not require hospitalization.

Although there were 39 different rotavirus infec- tions, there were 45 rotavirus-positive weeks because six children excreted rotavirus for two weeks. This gave a slightly higher excretion rate, 4.9 per 100 childmonths, and a prevalence-to-incidence ratio of $1: 2$.

3. Seasonality of rotavirus. Rotavirus was endemic throughout the observation period (figure 1 and table 4). However, as was observed in urban cases, children in the rural cohort experienced higher excretion rates during the cooler and drier months of the year (December through February). In 1982, February and October were peak months, each with a prevalence rate of 12.0 infections per 100 childmonths. In 1983, February and December showed high excretion rates of 13.8 and 12.1 infections per 100 child-months, respectively. In 1984, February
Figure 1. Excretion of rotaviruses by calendar months. Dots indicate rotavirus-positive weeks. Axis is skewed according to date of birth of children. Children's numbers are indicated on the left margin. All children except for three who were withdrawn from the study (nos. 1630, 1803, and 1923) were observed for two complete years.

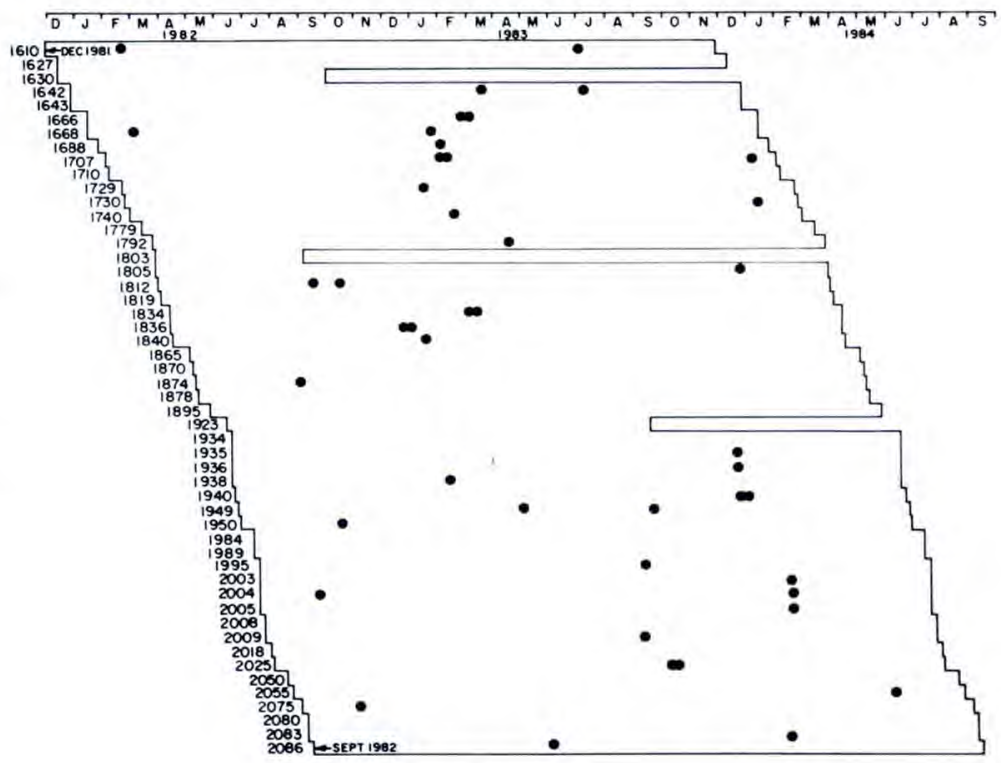


Table 4. Seasonality of rotavirus in Puriscal, 19821984.

\begin{tabular}{lccc}
\hline & \multicolumn{3}{c}{ Year } \\
\cline { 2 - 4 } Month & 1982 & 1983 & 1984 \\
January & $(n=242.5)$ & $(n=505.3)$ & $(n=169.8)$ \\
February & - & 9.3 & 7.9 \\
March & 12.0 & 13.8 & 11.9 \\
April & 8.5 & 9.1 & - \\
May & - & 2.5 & - \\
June & - & 2.1 & - \\
July & - & 2.5 & 7.6 \\
August & - & 4.7 & - \\
September & 9.6 & - & - \\
October & 12.0 & 7.2 & - \\
November & 2.9 & 5.3 & $\ldots$ \\
December & 2.4 & - & $\ldots$ \\
Novemb & & 12.1 & $\ldots$
\end{tabular}

NOTE. Figures represent the prevalence rate per 100 childmonths; - = rotavirus not detected; $n=$ observed child-months

peaked with a prevalence of 11.9 infections per 100 child-months. In order to study excretion rates by age, we selected peak months during which children of many ages were observed. Older children tended to exhibit higher excretion rates during months of excess frequency (table 5).

4. Rotavirus electropherotypes. Forty-five viral extracts from 32 children in the rural cohort were screened by PAGE. Twenty extracts that produced distinct bands by silver staining were electrophoresed again in two gels (figures 2 and 3). Similarly, 48 of 100 urban outpatients with rotavirus-associated diarrhea were screened and 10 of the extracts electrophoresed in one gel (figure 4). All strains (except for three inconclusive patterns shown in figure 3 ) belonged to segments 10 and 11 "long pattern," which correlates well with the antigenic reactivity of subgroup 2 virus. Strains from children in the rural co-

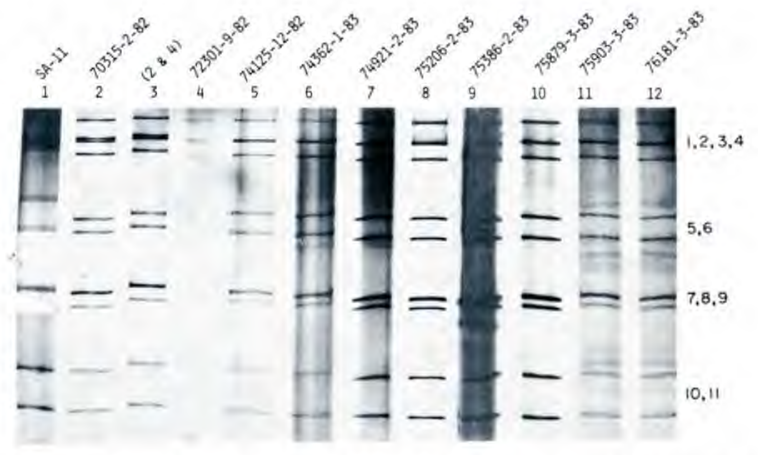

Figure 2. Silver-stained PAGE of rotavirus RNA from children in the rural cohort. Specimen numbers and collection dates are indicated on the top of the lanes. Electrophoresis was performed at $20 \mathrm{~mA} / \mathrm{gel}$ for $10 \mathrm{hr}$. Migration was towards the anode (bottom). Eleven segments of double-stranded RNA are distributed in four regions, as indicated on the right. Differences (diversity) in mobility arbitrarily defined the electropherotypes. Some bands are mixtures because segments were not separated under the conditions used. Simian SA-11 viral RNA was electrophoresed in lane 1 . See text for other details.

hort did not show much electrophoretic diversity; five electropherotypes were detected during the 33month study period. The viruses in lanes 1,3 , and 6 of figure 3 could not be subgrouped, but it should be noted that the virus in lane 6 showed an extra band in the region of the 5,6 segment doublet, as well as extra bands near the origin. It is unlikely that this particular strain would be a pararotavirus or a reovirus because it was detected by ELISA. Serotyping of this and other strains is currently under way at a World Health Organization collaborative center. In general, the electrophoretic diversity was greater in urban children with diarrhea than in children in the rural cohort. In the former, four electropherotypes were detected within a short span of time

Table 5. Prevalence of rotavirus by age during peak months in Puriscal, 1982-1983.

\begin{tabular}{|c|c|c|c|c|c|}
\hline \multirow[b]{2}{*}{ Age, months } & \multicolumn{2}{|c|}{1982} & \multicolumn{3}{|c|}{1983} \\
\hline & September & October & January & February & December \\
\hline $0-2$ & $14.3(7.0)$ & $3.9(0)$ & $\ldots$ & $\ldots$ & $\ldots$ \\
\hline $3-5$ & $7.8(25.5)$ & $5.8(17.3)$ & $11.8(0)$ & $4.8(0)$ & $\ldots$ \\
\hline $6-8$ & $6.5(0)$ & $5.3(18.8)$ & $14.1(7.1)$ & $18.5(5.4)$ & $\ldots$ \\
\hline $9-11$ & $2.5(0)$ & $1.8(0)$ & $12.0(16.7)$ & $11.6(17.3)$ & $\ldots$ \\
\hline $12-14$ & $\ldots$ & $\ldots$ & $5.1(20.0)$ & $8.3(36.1)$ & $0.9(0)$ \\
\hline $15-17$ & $\ldots$ & $\ldots$ & $\ldots$ & $\ldots$ & $14.3(7.0)$ \\
\hline $18-20$ & $\ldots$ & $\ldots$ & $\ldots$ & $\ldots$ & $9.9(30.2)$ \\
\hline $21-23$ & $\ldots$ & $\ldots$ & $\ldots$ & $\ldots$ & $7.8(0)$ \\
\hline
\end{tabular}

NOTE. Figures represent observed child-months (rate per 100 child-months). 


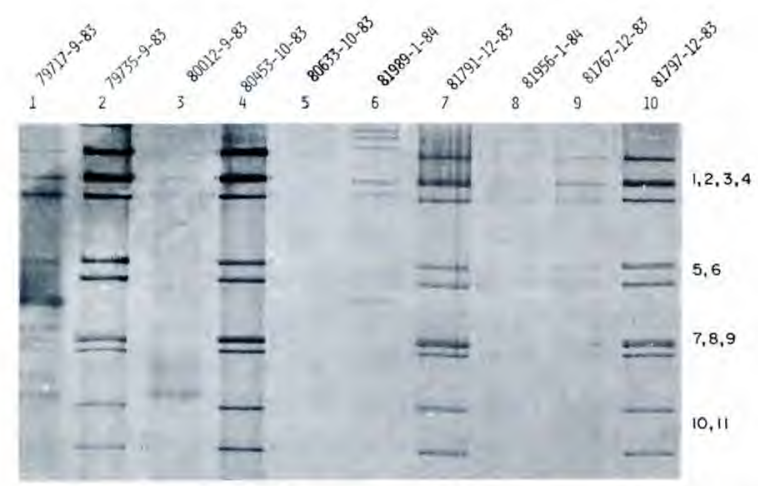

Figure 3. PAGE of rotavirus RNA from children in the rural cohort. See legend to figure 2 for details.

(May through December 1982; figure 4, lanes 2-6). Thereafter, a single electropherotype predominated.

Antibody to rotavirus. Rotavirus-specific IgA was detected in $65(2.6 \%)$ of 2,516 fecal supernatants, but it is not known whether it was maternally derived (from breast milk) or actively secreted by children. IgM to rotavirus was present in $12(0.5 \%)$ specimens; specific IgG was detected in only one specimen. Because rotavirus coproantibody did not persist in relation to total immunoglobulin content and because most children had already been weaned after 31 July 1983 , it was decided to assay specific coproantibody only in the fecal supernatants of specimens collected within four weeks of antigen detection rather than in all specimens (i.e., rotavirus positive and negative). Fifteen $(38.5 \%)$ of 39 cases occurred while children were breast-fed. In six (15.4\%) of 39 cases, specific coproantibody was demonstrated (table 6). Four of these six children were being breast-fed at the time of infection; specific IgM was found in two of the six children.

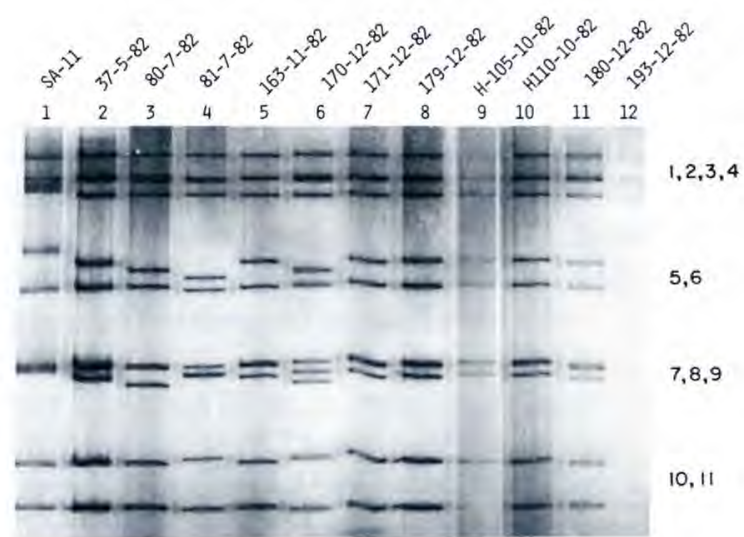

Figure 4. PAGE of rotavirus RNA from children in the urban cohort. See legend to figure 2 for details.

The presence of serum antibody correlated with prior fecal excretion of rotavirus in only $26(81.2 \%)$ of 32 cases; in six ( $18.8 \%$ ), specific serum antibody was not detected (table 6). It should be noted that rotavirus antigen was not detected in fecal specimens from the other six patients with specific serum antibody (table 5). Thus, the overall incidence based on serological means becomes marginally higher -0.6 infection per child-year rather than 0.5 per child-year (on the basis of viral shedding).

5. Nutritional status of children. At 12 months of age no child was $<75 \%$ of weight for age (II and III degrees of malnutrition) compared with the 50th percentile of the National Center for Health Statistics reference curve. At 24 months of age, one child exhibited II degree malnutrition. Rotavirus shedding was not found to be associated with periods of faltering growth.

Comparison series of children. One newborn child in comparison series no. 1 who was born at

Table 6. Serum immune responses and coproantibody to rotavirus in Puriscal, 1981-1984.

\begin{tabular}{|c|c|c|c|c|}
\hline Children & $\begin{array}{l}\text { No. of } \\
\text { children }\end{array}$ & $\begin{array}{c}\text { Sample } \\
\text { (type of antibody) }\end{array}$ & $\begin{array}{c}\text { No. positive/ } \\
\text { no. tested }\end{array}$ & $\begin{array}{c}\text { Percentage } \\
\text { with antibody }\end{array}$ \\
\hline $\begin{array}{l}\text { With rotavirus } \\
\text { antigen in feces }\end{array}$ & $32 *$ & fecal $(\operatorname{Ig} A)^{\dagger}$ & $6 / 39$ & 15.4 \\
\hline $\begin{array}{l}\text { With rotavirus } \\
\text { antigen in feces }\end{array}$ & $32 *$ & serum $(\operatorname{IgG})^{\ddagger}$ & $26 / 32 \S$ & 81.2 \\
\hline $\begin{array}{r}\text { Without rotavirus } \\
\text { antigen in feces }\end{array}$ & 14 & serum $(\operatorname{IgG}) \ddagger$ & $6 / 14 \S$ & 43.0 \\
\hline
\end{tabular}

* Seven children had repeat infections.

$\dagger$ Tested within four weeks of the detection of rotavirus in fecal specimens.

¥ Tested at two years of age.

$\S$ Forty-six different children were tested; serum was not collected from five children, including three who were withdrawn from the study. 
the Hospital San Juan de Dios was positive for rotavirus, but neither her older sister nor other members of the household were infected at the time. Neonates of the comparison series who were born at the Hospital Calderón Guardia (who were formula fed and separated from their mothers) were also negative for rotavirus. Subjects in comparison series no. 1 and no. 2 were not observed beyond the first week of life.

Intrafamilial cross-infection in 39 rural $(4.1$ persons per family) and 26 urban ( 5.2 persons per family) households was compared by testing fecal specimens from two to six contacts of each child with rotavirus. A rotavirus-positive household consisted of a rotavirus-positive child and at least one other positive member or contact of the household. In 39 rural households, stool samples from 154 contacts and rectal swabs from 96 domestic animals were tested. Excretion of virus was demonstrated in two of 39 households; one preschool-age sibling in one household and two teenaged relatives in another. These infections were asymptomatic. A cat was positive at the time one child from the rural cohort excreted rotavirus, but the specimen did not contain sufficient virus for electropherotyping. In 26 urban households, stool samples from 91 contacts were investigated. Twelve of 26 urban households were positive (vs. two of 39 rural households), a significant difference $\left(\chi^{2}=15.5 ; P<.001\right)$. Again, the excretors, eight adults and seven siblings, were asymptomatic.

\section{Discussion}

In 76.6 observed child-years only 51 episodes of diarrhea were recorded, an incidence of 0.7 episode per child-year. The incidence of rotavirus infection in the rural cohort was very low; 0.5 episode per child-year on the basis of virus shedding and $0.6 \mathrm{epi}$ sode per child-year on a serological basis. Interestingly, only five of 39 infections resulted in diarrhea, a pathogenicity of $12.8 \%$. Data from longitudinal studies in Cauqué, Guatemala [4]; Matlab, Bangladesh [10]; Winnipeg, Canada [11]; and Fortaleza, Brazil [12] can be compared with the results of the present study. In Cauqué, Matlab, and Fortaleza, all less-developed and poor communities, diarrhea rates were similar, ranging between 6.1 and 7.9 episodes per child-year. In the communities of Winnipeg (industrial) and Puriscal (transitional), diarrhea rates were lower -1.2 and 0.7 episodes per child-year, re- spectively. By contrast, rotavirus-associated diarrhea was highest in Cauqué ( 0.8 episode per child-year) and lowest in Puriscal ( 0.06 episode per child-year). Surprisingly, the incidence of rotavirus-associated diarrhea was similar in both Winnipeg and Matlab, but the rate in Matlab might be an underestimate since rectal-swab material was tested rather than whole feces. The pathogenicity of rotavirus varied considerably among children in Cauqué, Winnipeg, and Puriscal. The percentage of rotavirus infections associated with diarrhea was higher in Winnipeg $(80 \%)$ than in Cauqué $(65.7 \%)$ or Puriscal $(12.8 \%)$. In Fortaleza, the pathogenicity was $50 \%$ in 24 children under the age of two years who excreted rotavirus. Data from Matlab regarding asymptomatic infections were not available.

Assessment of the number of infective virions ingested by children is not possible, but children from Puriscal may have experienced a reduced exposure as compared with children from Cauqué as a result of a combination of factors, including rural conditions, good hygiene (frequent baths, potable water), and prolonged breast-feeding $(80.4 \%$ were breastfed for the first six months and $47 \%$ for a whole year). Regardless of immune factors, breast-feeding probably contributed to a reduced exposure because contaminated foodstuffs were not ingested. In Matlab and Cauqué, the highest incidence rates of rotavirus-associated diarrhea coincided with the peak periods of weaning $[4,10]$.

There are indications that the virulence of rotavirus is associated with serotype [13]. It is possible that a proportion of strains from Puriscal belong to the less-virulent serotypes 3 and 4 . Alternatively, the observed low pathogenicity may have been independent of serotype and influenced by selective host environmental pressures. This study confirms observations in tropical countries where rotavirus remains endemic throughout the year $[1,4,14]$. Year-round excretion probably favors attenuation and reduces the number of susceptibles in a given month.

Neonatal infection with rotavirus has been reported as a common phenomenon in British, Australian, and Venezuelan maternity hospitals [15-17]. Such infection is probably nosocomial, with house staff acting as the main disseminators. In Costa Rica, significant nosocomial infection has been documented among ill neonates at the National Children's Hospital [18]. The two large hospitals that we surveyed, however, do not as a rule treat infants and young children with diarrhea, and their staff may not have 
contaminated newborn babies. Certainly the size of the sample of newborns in this study was small, and it may be premature to exclude the possibility of nosocomial infection in neonates until a systematic search is undertaken.

Cross-infection between rural household members of positive children was significantly lower than that in urban ones. In the more crowded urban households, children with diarrhea probably shed considerably more virus in contrast to rural children, who tended to excrete virus asymptomatically in their smaller family units. It is generally accepted that siblings and adults act as reservoirs of the infection, but children with diarrhea are certainly the main disseminators of the virus $[19,20]$.

Five of the seven children who experienced reinfections excreted subgroup 2 virus asymptomatically on both occasions. (The strains from the other two children gave inconclusive electropherograms and could not be subgrouped.) Reinfection with virus of the same subgroup has also been demonstrated in Great Britain [21]. Reinfection may be a common rather than a sporadic phenomenon in certain populations. In Cauqué, all but one of the 45 children experienced two or more infections in their first three years of life [4]; reinfection was the rule rather than the exception.

Electrophoretic diversity was higher in strains from the children in the urban cohort than those from the rural cohort. Costa Rican strains followed the pattern described for Mexico [22] and Australia [23], where predominance developed from among a mixed population of electropherotypes. In Melbourne for instance, 17 electropherotypes were identified over a nine-year period, and they showed a sequential pattern of occurence with a limited number being detected at any one time [23]. In some settings, however, diversity seems to be higher. Thus, nine electropherotypes were identified among 85 Indonesian children [24], and as many as 32 electropherotypes were detected in 142 cases of rotavirus-associated diarrhea in Chile [25]. By contrast, in a more isolated community in Papua New Guinea, a single electropherotype was identified in 33 cases of rotavirus-induced diarrhea [26].

Immunity to rotavirus is thought to be largely antibody mediated since both infection and diarrhea can be prevented by ingestion of antibody-rich preparations [27-29]. Secretory antibody has been detected during or shortly after rotavirus-associated diarrhea [30-32], and although it wanes rapidly, it is thought to be important in the termination of infection. In Puriscal, however, specific IgA coproantibody was detected in only six of 39 patients, including four children who were breast-fed at the time of infection. Children from Puriscal may have failed to produce secretory responses because gut lymphocytes were not primed, a result of breast-feeding. A similar argument may explain the lack of serum antibody in 10 children with documented infections. This has been observed in breast-fed children from China who experience a delay in the appearance of rotavirusspecific IgG [33]. On the other hand, there are indications that a certain threshold of mucosal damage must be reached before secretory antibody is elicited [34]. Thus, a proportion of children from Puriscal may have failed to produce antibody to rotavirus because they experienced mild or asymptomatic infections.

A rotavirus vaccine may be a useful adjunct to the campaign to reduce morbidity due to diarrheal disease, particularly in less-developed countries. For instance, in rural settings such as Guatemala, Bangladesh, and Brazil and in urban areas such as Winnipeg, Canada (where rotavirus pathogenicity is high), a vaccine would be particularly useful. For Costa Rica, vaccination programs should be aimed at reducing the epidemicity among urban children who are prematurely weaned and live in crowded conditions. Among rural Costa Rican children like those studied here, vaccination would not be expected to have much effect. Rather, education and environmental sanitation, as part of the primary health care approach, and a continued emphasis on improved personal hygiene, as is stressed in Costa Rica [35], seem to be more logical avenues for control and prevention of all diarrheas of infectious origin.

\section{References}

1. Mata L, Simhon A, Padilla R, Gamboa MM, Vargas G, Hernandez F, Mohs E, Lizano C. Diarrhea associated with rotaviruses, enterotoxigenic Escherichia coli, Campylobacter and other agents in Costa Rican children, 1976-1981. Am J Trop Med Hyg 1983;32:146-53

2. Mata L, Allen MA, Jiménez P, Garcia ME, Vargas W, Rodríguez ME, Valerín C. Promotion of breast feeding, health and growth among hospital-born neonates, and among infants of a rural area in Costa Rica. In: Chen LS, Scrimshaw NS, eds. Diarrhea and malnutrition. Interactions, mechanisms and interventions. New York: Plenum Press, 1983:177-202

3. Kapikian AZ, Yolken RH, Greenberg HB, Wyatt RG, Kalica AR, Chanock RM, Kim HW. Gastroenteritis viruses. In: Lennette EH, Schmidt NJ, eds. Diagnostic procedures for 
viral, rickettsial and chlamydial infections. 5th ed. Washington, DC: American Public Health Association, 1979: 927-95

4. Mata L, Simhon A, Urrutia JJ, Kronmal RA, Fernández R, García B. Epidemiology of rotoviruses in a cohort of 45 Guatemalan Mayan Indian children observed from birth to the age of three years. J Infect Dis 1983;148:452-61

5. Schnagl RD, Rodger SM, Homes IH. Variation in human rotavirus electropherotypes occurring between rotavirus gastroenteritis epidemics in Central Australia. Infect Immun 1981;33:17-21

6. Laemmli UK. Cleavage of structural proteins during assembly of the head of bacteriophage T4. Nature 1970;227:680-5

7. Herring AJ, Inglis NF, Ojeh CK, Snodgrass DR, Menzies JD, Rapid diagnosis of rotavirus infection by direct detection of viral nucleic acid in silver-stained polyacrylamide gels. J Clin Microbiol 1982;16:473-7

8. McLean B, Sonza S, Holmes IH. Measurement of immunoglobulin $\mathrm{A}, \mathrm{G}$ and $\mathrm{M}$ class rotavirus antibodies in serum and mucosal secretions. J Clin Microbiol 1980;12:314-9

9. Simhon A. Rotavirus infection and immune response patterns in urban English and rural Costa Rican children from a transitional area. $\mathrm{PhD}$ diss, London: University of London, 1984

10. Black RE, Brown KH, Becker S, Alim ARMA, Huq I. Longitudinal studies of infectious diseases and physical growth of children in rural Bangladesh. II. Incidence of diarrhea and association with known pathogens. Am J Epidemiol 1982;115:315-24

11. Gurwith M, Wenman H, Hinde D, Feltham S, Greenberg H. A prospective study of rotavirus infection in infants and young children. J Infect Dis 1981;144:218-24

12. Guerrant RL, Kirchhoff LV, Shields DS, Nations MK, Leslie J, de Sousa MA, Araujo JG, Correia LL, Sauer KT, McClelland KE, Trowbridge FL, Hughes JM. Prospective study of diarrheal illnesses in Northeastern Brazil: patterns of disease, nutritional impact, etiologies, and risk factors. J Infect Dis 1983;148:986-97

13. Wyatt RG, James HD Jr, Pittman AL, Hoshino Y, Greenberg HB, Kalica AR, Flores J, Kapikian AZ. Direct isolation in cell culture of human rotaviruses and their characterization into four serotypes. J Clin Microbiol 1983;18: $310-7$

14. Viera de Torres B, Mazzali de Ilja R, Esparza J. Epidemiological aspects of rotavirus infection in hospitalized Venezuelan children with gastroenteritis. Am J Trop Med Hyg 1978;27:567-72

15. Chrystie IL, Totterdell BM, Banatvala JE. Asymptomatic endemic rotavirus infections in the newborn. Lancet 1978;1: $1176-8$

16. Bishop RF, Cameron DJS, Veenstra AA, Barnes GL. Diarrhea and rotavirus infection associated with differing regimens for postnatal care of newborn babies. J Clin Microbiol 1979;9:525-9

17. Perez-Schael I, Daoud G, White L, Urbina G, Daoud N, Perez M, Flores J. Rotavirus shedding by newborn children. J Med Virol 1984;14:127-36

18. Odio C, Hernández F, Ruiz MA, Padilla R, Mohs E. Rotavirus en un servicio de neonatologia: descripción de una epidemia. Revista Médica del Hospital Nacional de Niños (Costa Rica) 1980;2:59-72
19. Kapikian AZ, Kim HW, Wyatt RG, Cline WL, Arrobio JO, Brandt CD, Rodriquez WJ, Sack DA, Chanock RM, Parrott $\mathrm{RH}$. Human reovirus-like agent as the major pathogen associated with "winter" gastroenteritis in hospitalized infants and young children. N Engl J Med 1976;294:965-72

20. Wenman WM, Hinde D, Feltham S, Gurwith M. Rotavirus infection in adults: results of a prospective family study. N Engl J Med 1979;301:303-6

21. Simhon A, Chrystie IL, Totterdell BM, Banatvala JE, Rice SJ, Walker-Smith JA. Sequential rotavirus diarrhoea caused by virus of same subgroup [letter]. Lancet 1981; 2:1174

22. Espejo RT, Muñoz O, Serafin F, Romero P. Shift in the prevalent human rotavirus detected by ribonucleic acid segment differences. Infect Immun 1980;27:351-4

23. Rodger SM, Bishop RF, Birch C, McLean B, Holmes IH. Molecular epidemiology of human rotoviruses in Melbourne, Australia, from 1973 to 1979 , as determined by electrophoresis of genome nucleic acid. J Clin Microbiol 1981;13:272-8

24. Albert MJ, Soenarto Y, Bishop RF. Epidemiology of rotavirus diarrhea in Yogyakarta, Indonesia, as revealed by electrophoresis of genome RNA. J Clin Microbiol 1982;16: 731-3

25. Spencer E, Avendaño F, Araya M. Characteristics and analysis of electropherotypes of human rotavirus isolated in Chile. J Infect Dis 1983;148:41-8

26. Albert MJ, Bishop RF, Shann FA. Epidemiology of rotavirus diarrhea in the highlands of Papua, New Guinea, as revealed by electrophoresis of genome RNA. J Clin Microbiol 1983;17:162-4

27. Snodgrass DR, Wells PW. Passive immunity in rotaviral infections. J Am Vet Med Assoc 1978;173:565-8

28. Fahey KJ, Snodgrass DR, Campbell I, Dawson AMcL, Burrells C. IgG antibody in milk protects lambs against rotavirus diarrhoea. Vet Immunol Immunopathol 1981;2:27-33

29. Barnes GL, Doyle LW, Hewson PH, Knoches AML, McLellan JA, Kitchen WH, Bishop RF. A randomised trial of oral gammaglobulin in low-birth-weight infants infected with rotavirus. Lancet 1982;1:1371-3

30. Sonza S, Homes IH. Coproantibody response to rotavirus infection. Med J Aust 1980;2:496-9

31. Davidson GP, Hogg RJ, Kirubakaran CP. Serum and intestinal immune response to rotavirus enteritis in children. Infect Immun 1983;40:447-52

32. Kapikian AZ, Wyatt RG, Levine MM, Yolken RH, VanKirk DH, Dolin R, Greenberg HB, Chanock RM. Oral administration of human rotavirus to volunteers: induction of illness and correlates of resistance. J Infect Dis 1983;147: 95-106

33. Echeverria P, Blacklow NR, Ho MT, Cukor G, Beasley RP. Age distribution of antibody to reovirus-like agent in children in Taiwan. J Pediatr 1977;91:960-2

34. Riepenhoff-Talty M, Bogger-Goren S, Li P, Carmody PJ, Barrett HJ, Ogra PL. Development of serum and intestinal antibody response to rotavirus after naturally acquired rotavirus infection in man. $\mathrm{J}$ Med Virol 1981;8:215-222

35. Mata L. Evolution of diarrhoeal diseases and malnutrition in Costa Rica. The role of interventions. Assignment Children 1983;61/62:195-224 